\title{
PROBLEM BASED LEARNING (PBL) IN TEACHER EDUCATION: A REVIEW OF THE EFFECT OF PBL ON PRE-SERVICE TEACHERS' KNOWLEDGE AND SKILLS
}

\author{
Mohamad Termizi Borhan \\ UNESCO Chair in Problem Based Learning, Department of Development \\ and Planning, Aalborg University, Denmark Faculty of science and \\ Mathematics Universiti Pendidikan Sultan Idris, Malaysia
}

\begin{abstract}
Inspired by positive results of Problem Based Learning (PBL) implementation within an array of disciplines, PBL was also implemented in teacher education fields since 1980's. Since then, the literature of PBL implementation and its effect in teacher education is growing. However, there is no review work reported to conclude on how PBL effect specific learning outcome in teacher education fields. Hence the aim of the paper is to review the research evidences concerning the effect of PBL implementation on pre-service teachers' knowledge and skills. Resources (journal articles and proceedings) were obtained from bibliographic databases and key research journals. The resources were chosen based on specific inclusion criteria, followed by a common review framework to ensure commonality and comprehensiveness during the review. The review works concluded that a PBL experience within teacher education provides opportunities for preservice teachers to simultaneously acquire knowledge and develop skills deemed important for the future teachers.
\end{abstract}

Keywords: Problem based learning; pre-service teacher; teacher education; knowledge; skills

\section{Introduction}

Call for the excellence in teaching and learning in higher education and university graduates with skills and competences is inevitable due to the results of globalization. Pedagogical practices in higher education is urge to reflect and corroborate for a more than knowledge-laden graduates. Lecturebased pedagogy, which dominantly represents the classroom practices in higher education is no longer sufficient to prepare such traits of graduates. 
There is a need for the adoption of a more student-centred learning to address these calls. In recent years, Problem Based Learning (PBL), a learning approach that aligned with the social constructivist framework has become one of the promising innovations in higher education teaching and learning settings. PBL stand on premises for advocating learner-centred learning approach where students are problem-solvers, think in critical and creative way, active involvement in generating knowledge, the lecturer/tutor assumes a coaching or facilitating role, serving as a cognitive coach by monitoring, probing, challenging and scaffolding students in solving multifaceted problems and the problem is focused on the learning processes from which content is derived (Tan, 2003; Edens, 2000; Savin-Baden, 2000 and Major and Palmer, 2001).

Since its inception about 40 years ago in a medical educational program at McMasters University (Barrows, 1996), PBL has evolved in many institutions worldwide and extensively applied in myriad fields such a architecture, law and social work (Bould and Feletti, 1991) and professional education such as nursing, design, engineering, optometry, architecture, law and business (Chappel and Hager, 1995). The flexibility and diversity of PBL make it possible to be incorporated in different ways, in variety of subjects and disciplines and in various contexts (Savin-Baden, 2001). Given the perceived advantages of PBL in other fields, there would appear to be a good case for the introduction of this teaching and learning approach within teacher education. In fact, PBL approach has become the centre stage in teacher education since 1980s (Merseth, 1996).

\section{PBL and Teacher Education}

In teacher education fields, PBL has been implemented in both graduate and undergraduate level and in variety of courses like Foundations of Education, Inclusion Classrooms, Elementary School Curriculum, Introductory Educational Psychology, Educational Research and Methods (Levin, 2001), and Science Education (Watters, 2007, Goodnough, 2003 and Peterson and Treagust, 2001). The drivers for PBL implementation in teacher education field are varied from one case and another, but mostly devoted to better prepare the teacher graduates to be more relevant in their teaching professions. Generally, teacher's role in schools are now changing from merely imparting the knowledge to the one that inculcate creativity, intellectuality, problem solving ability and critical thinking skills among students. Beginning teachers need to be equip themselves with necessary skills, attitudes and disposition to correspond with the ever-changing and complexity of the school classrooms such as diversity of students' background, inclusive classrooms and ongoing development of technologies (Dean, 1998 and Goodnough, 2006). 
In response to this call, PBL is seen as a platform to enhance preservice teachers's acquisition of knowledge and skills, and to prepare them for varied roles of a teacher through authentic scenarios, group collaborations and self-directed learning. Finkle and Torp (1995) described PBL as a curriculum development and instructional system that simultaneously develop both problem solving strategies and disciplinary knowledge and skills by placing the pre-service teachers in the active role of problem solvers confronted with an "ill-structured" problems that reflect real world problem and have more than one feasible solutions. PBL encompasses problems that influence both theory and practice. De Simone (2008) contended how a problem scenario that represent real-life problems could lead to enhance pre-service teachers ability to define the problems, generate solutions, and application of practical and literature-based resources in search for problem`s solution. Likewise, McPhee (2002) put forth how teacher education fields is compliant with PBL approach. The author suggests the teacher education itself should be seen in the frame of constructivism and devoted, but not limited to, child-centred perspective. For instance, a problem scenario of "an excel, highly motivated secondary school students with the sudden drop off of achievement, and change in behaviour" will serve the opportunity for pre-service teachers to explore interrelated issues like motivation, learning theories, learning behaviour, and national standard and policy. Therefore, from a specific problem scenario in a PBL approach, pre-service teachers will have the opportunity to experience interdisciplinary learning, which represent the central principles of PBL. Peterson and Treagust (2001) posit that the knowledge (content knowledge, curriculum and learners) integration and call to have lifelong learners in teacher education serves teacher education as appropriate for a PBL implementation.

In general term, Levin (2001) provides an argument for the relevant of PBL application in teacher education course. The important to redesign an undergraduate teacher education course is to make learning more relevant and engaging, to help pre-service teachers perceived their profession as a true profession worthy of their intelligent and passion. In similar arguments, Dean (1999) seen PBL as an important vehicle to expose the pre-service teachers to the situation that they are likely to face as professional educators whilst simultaneously practicing a teaching and learning approach that encapsulates the central tenet of constructivist and social constructivist learning theory.

\section{Review Works of PBL Implementations and its Effects}

Most of the review works to date are devoted for medical education (e.g. Albanese and Mitchell, 1993; Vernon and Blake, 1993; Norman and 
Schmidt, 2000; and Colliver, 2000) measuring the effectiveness of PBL approach over traditional or didactic methods. In general, these works concluded that PBL students perform better on clinical knowledge acquisition and skills, while their peers in conventional curriculum perform better on basic science knowledge acquisitions. Dochy's et al., (2003) metaanalysis and systematic review by van den Bossche (2000) on the effects of PBL concentrating on knowledge and skills across variety of fields further verified the above findings. Dochy et al., (2003) analyse 43 empirical studies on PBL in higher education articles and finding suggests a robust positive effects on students' skills albeit there is a tendency to negative effects when looking on the effect of PBL on the knowledge. van den Bossche's (2000) systematic review also yielded the same result pattern where PBL has positive effects on students' skills but negative effect on their knowledge. However, a literature review conducted by Colliver (2000) suggest a contradict results. The author found there was no substantial evidence that PBL improve neither knowledge nor clinical performance of students.

To my knowledge on existing literature, albeit the literature of PBL in teacher education is growing, there are no review reports on the implementation of PBL in teacher education. Reflecting on the cumulative empirical evidence on how PBL effect pre-service teachers' knowledge and skills holds the potential to refine its employment, and contemplating any rooms of improvement, which will subsequently leading to an improved constructivist learning experience for pre-service teachers. In addition, this review works will contribute to the knowledge gap of the scarcity of PBL implementation in teacher education programme (Kwan, 2008 and Chappel and Hager, 1995). Hence this paper reports the findings from a review work of research evidence of PBL implementation in teacher education focusing on the knowledge and skills acquisitions of pre-service teachers.

\section{Method}

In literature review works, previous empirical research articles serve as the sources. To search for the relevant empirical research articles for review purposes, searching techniques are aim to be rigorous and thorough, so that the review will represent most of the articles, if it is not all. Preliminary review works started by retrieving the articles through several bibliographic databases for education and social science research like Educational Resources Information Center (ERIC), British Educational Index, Web of Science (for Science Citation Index, Social Science Citation and Art and Humanities Citation Index), PsycINFO, searches in key research journals (e.g. European Journal of Teacher Education and Asia Pacific Journal of Teacher Education) and searches in System for Information on Grey Literature in Europe (SIGLE) for grey literatures. Subject headings and 
keywords based on 'problem based learning' were combined with 'teacher education' and 'pre-service teachers' that produced number of titles. The periodic indices and content table of issues were search manually by reading the abstracts, aiming to identify studies that address the effect of PBL on preservice teachers' knowledge and skills. Table I specified the selection criteria determined at the outset of the study to select suitable articles for inclusion in the reviews. Upon completing the selection criteria, several relevant articles were recognized as suitable and relevant to the objective under study.

\section{Table I: Four criteria to determine papers for reviews.}

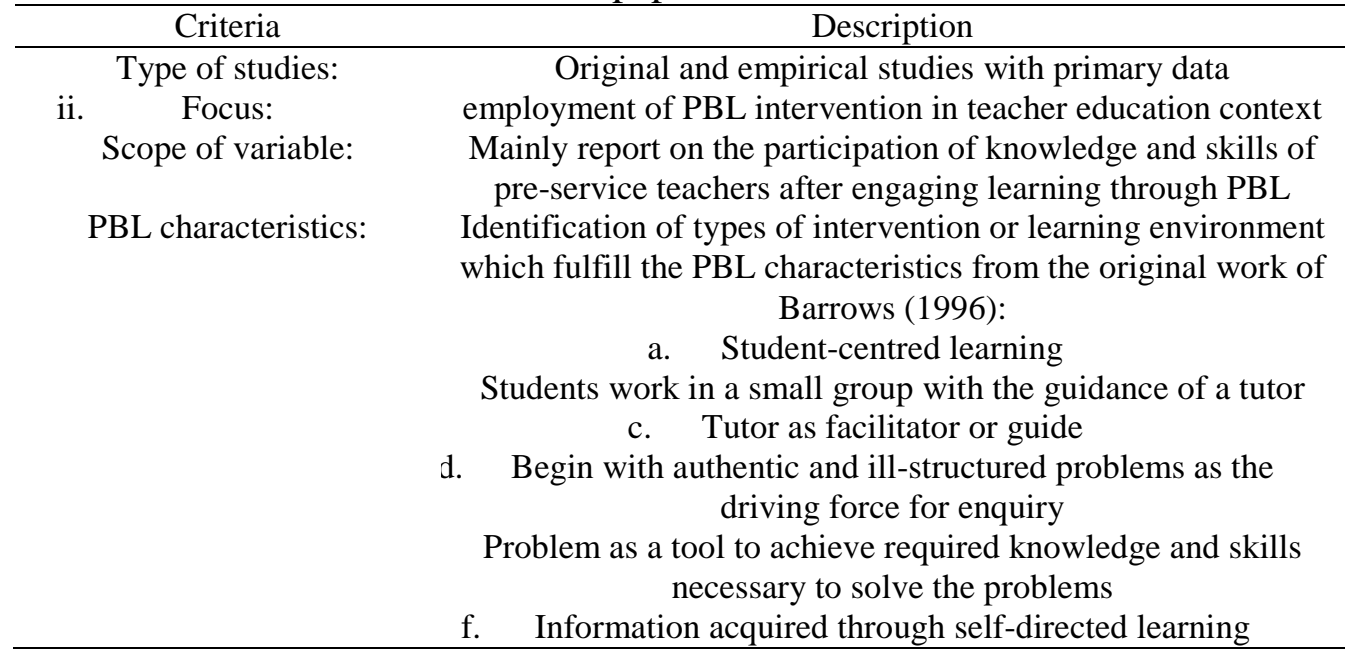

This yielded relevant articles under the studies. Next, the snowball method was employed, i.e. reading selected articles which led to the identification of further relevant sources. Rickinson (2001) posits this methods as a means to achieve comprehensiveness in a literature search, in which the search process is continuous until no new citations emerge. Following the selection criteria, each individual article underwent reviewing processes. Table II describes the review framework established to ensure commonality and comprehensiveness of review the works among the selected articles.

Table II: The review framework for selected articles

\begin{tabular}{cc}
\hline Component & Description \\
\hline i. & $\begin{array}{c}\text { A summary of the aims of the research study as } \\
\text { reported by the researcher in their paper } \\
\text { Summary of the key theoretical/conceptual } \\
\text { assumptions that underpin the work reported (but } \\
\text { only in so far as these are explicated and } \\
\text { acknowledged by the authors) }\end{array}$ \\
iii. $\quad$ Methodology & $\begin{array}{c}\text { The broader epistemological and theoretical } \\
\text { framework that surround and underpin the method }\end{array}$
\end{tabular}


iv. Validity measures

v. Methods

vi. Main findings

vii. Key conclusions of the study (only in so far as these are explicated and knowledge

A value aim at measuring validity or reliability (howsoever conceived) that are reported by the author

Summarized detailed of the reported procedures of data collection and data analysis

Summary of the study's main findings as reported by the author

Summary of the main conclusions drawn from the study's findings by the author.

(derived after Rickinson (2003), pg.271)

\section{Results}

\section{Skills}

It is widely enunciate that PBL fosters skill development and skill acquisition among the learners. As in teacher education field, the call for the pre-service teachers to develop and equip with critical and analytical abilities to deal with the complexities and diversities of their classroom is inevitable. Consonant to this calls, PBL is seen as a vehicle for skills inculcation since its emphasize active learning experiences that pre-service teachers should be engage during their teaching preparation course. The first research evidence of skills acquisitions were from Edwards and Hammer (2004) in their research on pre-service teachers and change towards PBL. The authors concluded that the PBL approach is particularly suited for teacher education as it offers them the opportunity to acquire skills and theoretical content relevant to their future careers within the reflective safety of the university environment. Furthermore, pre-service teachers also associated the benefit of participating in a PBL scenario that deals with the realistic nature of the experience and saw the opportunity to develop skills considered to be necessary to them as future teachers.

De Simone (2008) measured pre-service teacher`s problem solving skills between experimental class (PBL approach) and control group (traditional approach). The author found out that experimental group exhibit better skills in constructing the central problem, elaborate the problem, connection between solution and problem and used of multiple resources. Similarly, Senocak et al.,( 2007) employed a quasi-experimental research design to compared the achievement of pre-service science teachers on PBL curriculum and conventional methods in learning about gases. Apart from measuring the achievements, four different scales were developed to gauge experimental groups' evaluation of PBL. PBL has successfully developed pre-service teachers' necessary skills, such as critical thinking, literature searching, self-directed learning and problem solving. These findings are supported by Taplin and Chan's (2001) research outcome. The authors 
observed the development of skills and understanding of pre-service teachers as problem solvers. The use of journal entries and evaluation forms to probe pre-service teachers' self-reflection as problem solvers and possible change in their thinking about teaching yielded mixed results. Although the preservice teachers do not favour to tackle the pedagogical problems and reluctant to make their own decision to solve the problems presented, they showed ability to develop appropriate problem solving strategies skills and understanding in short time.

Murray-Harvey and Slee (2000) applied PBL in attempts to help preservice teachers make connection and applying their online learning to life. To measure the impact of PBL, the authors used their feedback and peer reflection as the resources. Evaluation of pre-service teachers' responses showed their agreement that PBL process help developed their critical skills, reflective skills and skills needed by teaching professions. McPhee (2002) used pre-service teachers' learning feedback and questionnaires to investigate their experience in issues-based learning in the classes. The preservice teachers described the benefits of PBL as the way to improve their communication skills, team working and information gathering and selecting and analytical skills. Murray-Harvey et al., (2004) evaluate pre-service teachers' assessment of their learning in PBL environment across four area of skills development: group processes; problem solving; knowledge building; and, interpersonal skills through a self-rating of tutorial performance questionnaire. To determine any growth of these competences between two case studies, the authors run a statistical test and found out that on all competences, pre-service teachers had a significant increment in their performances and skills across two case studies.

\section{Knowledge}

In documenting the research evidence of the knowledge acquisition of pre-service teachers after participating in PBL, there are two categories of knowledge reported: 1.Pedagogical Content Knowledge (PCK), and 2. Conceptual content knowledge. PCK is a notion first used by Shulman and define as "the most powerful analogies, illustrations, examples, explanations and demonstrations- in a word the ways of representing and formulating the subject, that make it comprehensible for others" (Shulman, 1986). Despite criticism that PBL emphasize in higher order thinking and problem solving skills at the expense of low level knowledge acquisitions, there are some research evidences to suggest PBL is also promote knowledge acquisitions.

Inspired by the limitation of science knowledge among teachers, Peterson and Treagust (1998) developed a PBL learning framework that address pre-service teachers' knowledge base for teaching (science content knowledge, curriculum knowledge and knowledge of the learner) and 
pedagogical reasoning ability (comprehension, transformation, instruction, evaluation, reflection and new comprehension). Using case studies as way to elicit the effect of PBL, pre-service teachers have been reported to develop their knowledge base and pedagogical reasoning that correspond to their current belief in primary teaching and student learning. So and Kim (2009) integrate PBL in information and communication technology (ICT) to better prepare future teachers of having pedagogically sound technology integration, or in particular technological pedagogical content knowledge (TPCK). From the surveys and the lesson design artefacts, pre-service teachers has had understandings of pedagogical knowledge about PBL, despite reporting of having difficulty to crafting authentic and ill-structured problems and designing tasks with a balance between teacher guidance and student independence. In her effort preparing pre-service science teachers

The concept of conceptual knowledge is defined as the amount and organization of subject matter knowledge held in the mind (Shulman, 1986). Askell-William et al., (2005) investigated pre-service teachers' written reflection to elicit the changes in their mental model of teaching and learning following the experience of a PBL activity. From the categories derive from pre-service teachers' manuscript, it is evidence that PBL process, especially related to the case study expand their knowledge about factors influence child development. Kwan (2008) gauge learning experiences of pre-service teachers towards 3 modes of PBL delivery, namely Mode 1: The classical PBL, Mode 2: The Alternate PBL and Mode 3: The Modified Model. The findings suggested that both Mode 1 and Mode 3 were deemed feasible by pre-service teachers in constructing their knowledge because its require substantial mental processes that lead to meaningful discussion (Mode 1), and they are able to cover broader perspective of factual knowledge within limited class time (Mode 3). In preparing future teachers for teaching with technology, Albion and Gibson (2000) combine an interactive multimedia (IMM) packages based on PBL principles to help pre-service teachers integrate technology in their teaching and learning sessions. Their evaluation of the approach elicited from a survey revealed that pre-service teachers gained insights and knowledge in technology, self- organization and classroom management.

\section{Summary}

Across an array of university courses and programme, PBL implementation in higher education is strive to forge the university learning with the real world of professionals. The central tenets of PBL that highly emphasize the disciplinary knowledge integration and development of higher order thinking skills by placing the learners in active role confronted with the ill-structured problems accelerate the merge between both worlds. In teacher 
education fields, PBL is used to adequately prepare pre-service teachers for the realities of teaching. School-based assessment, inclusion of generic skills in school curriculum and shift toward outcome based education are among the seminal issues that create a call to prepare teachers that both knowledgeable and skilful. From the collective empirical evidences of effect of PBL implementation on pre-service teachers' skill and knowledge acquisitions, it is clear that PBL enhanced their knowledge and skills. The current review works have shown that PBL appears to be appropriate in inculcating skills demanded in teaching profession such as information processing-related skills, critical thinking skills, self-directed learning skills, problem solving skills and social skills. Though PBL emphasize skills acquisition over knowledge, knowledge acquisition is seen as equally important as skills for the pre-service teachers. From all the empirical evidences reviewed, it is in agreement that PBL address both pre-service teachers PCK and conceptual knowledge. Both type of knowledge are particularly important to acquire by pre-service teachers for them to be relevant in teaching professions. As Peterson and Treagust (1998) suggest, PBL in teacher education could converge in addressing the development of content knowledge and PCK, and the central characteristics of PBL problems could lead to the development of range of knowledge from curriculum knowledge to how children learn. It is concluded that a PBL experience within teacher education provides opportunities for pre-service teachers to simultaneously develop skills and acquire knowledge.

\section{Bibliography:}

Albanese, M., and Mitchell, S. (1993). Problem-based learning: a review of literature on its outcomes and implementation issues. Academic Medicine: Journal of the Association of American Medical Colleges, 68 (1), 52-81.

Albion, P. R., and Gibson, I. W. (2000). Problem-based learning as a multimedia design framework in teacher education. Journal of Technology and Teacher Education, 8(4), 315-326.

Askell-William, H., Murray-Harvey, R., and Lawson, M. J. (2005). Extending teacher education students' mental models of teaching and learning through Problem Based Learning. Paper presented at the 2005 Annual Conference of the Australian Association for Research in Education, Sydney, November 28 ${ }^{\text {th }}$, 2005.

Barrows, H. S. (1996). Problem-based learning in medicine and beyond: a brief overview. In L. Wilkerson, and W. H. Gijselers (Eds.), New direction for teaching and learning, 68(3-11). San-Francisco: Jossey-Bass Publishers. Boud, D., Feletti, G. (Eds.). (1991). The challenges of problem-based learning. New York: St. Martin's Press. 
Chappel, C. S., and Hager, P. (1995). Problem-based learning and competency development. Australian Journal of Teacher Education, 20, 1-7. Colliver, J. (2000). Effectiveness of problem based learning curricula. Academic Medicine, 75, 259-266.

Dean, C. (1998). PBL and meeting the challenges of teacher education. Retrieved January 30, 2012, from http://www.samford.edu/pubs/pbl/pblins1.pdf.

Dean, C. D. (1999). Problem-based learning in teacher education. Paper presented at the Annual Meeting of the American Educational Research Association (Montreal, Quebec, Canada, April 19-23, 1999).

De Simone, C. (2008). Problem-Based Learning: a framework for prospective teachers` pedagogical problem solving. Teacher Development, 12(3), 179-191.

Dochy, F., Segers, M., Van den Bossche, P. and Gijbels, D. (2003). Effects of problem-based learning: a meta-analysis. Learning and Instruction, 13, 533-568.

Edens, K. M. (2000). Preparing problem solvers for the $21^{\text {st }}$ century through problem-based learning. College teaching, 48(2), 55-69.

Edwards, S. \& Hammer, M. (2004). Teacher education and Problem-Based Learning: Exploring the issues and identifying the benefits. Paper presented at the International Conference of the Australian Association for Research in Education. Melbourne, November.

Finkle, S. L., and Torp, L. L. (1995). Introductory Documents. Illinois Math and Science Academy. Aurora, Illinois.

Goodnough, K. (2003). Preparing pre-service science teachers: Can problembased learning help? Paper Presented at the Annual Meeting of the American Educational Research Association(84 ${ }^{\text {th }}$, Chicago, IL, April, 21-25, 2003).

Goodnough, K. (2006). Enhancing pedagogical content knowledge through self-study: an exploration of problem-based Learning. Teaching in Higher Education, 11(3), 301-318.

Kwan, T. Y. L. (2008). Student-teachers' evaluation on the use of different modes of problem-based learning in teacher education. Asia Pacific Journal of Teacher Education, 36(4), 323-343.

Levin, B. B. (Eds.). (2001). Energizing teacher education and professional development with problem-based learning. Alexandria, VA: Association for Supervision and Curriculum Development.

Major, C. H., and Palmer, B. (2001). The effectiveness of problem-based learning in higher education: lessons from the literature. Academic Exchange Quarterly, 5(1).

McPhee, A. (2002). Problem Based Learning in initial teacher education: taking the agenda forward. Journal of Educational Enquiry, 3(1), 60-78. 
Merseth, K. K. (1996). Cases and case method in teacher education. In Handbook of Research on Teacher Education, ed. J. Sikula, 722-44. $2^{\text {nd }}$ ed. New York: Macmillan.

Murray-Harvey, R. and Slee, P. (2000). Problem based learning in teacher education; Just the beginning. Paper presented at the annual conference of the Australian Association for Research in Education, Sydney, Australia, 4-6 December 2000.

Murray-Harvey, R. Curtis, D. D., Cattley, G., and Slee, P. (2004). Enhancing learners'generic skills through Problem-Based Learning. Paper presented for the annual conference of the Australian Association for Research in Education, Melbourne, Australia. November 28-December 2, 2004.

Norman, G. R., and Schmidt, H. G. (2000). Effectiveness of problem-based learning curricula: theory, practice and paper darts. Medical Education, 34, 721-728.

Peterson, R. F. and Treagust, D. F. (1998). Learning to teach primary science through problem-based learning. Science Education, 82, 215-237.

Peterson, R. F. and Treagust, D. F. (2001). A problem-based learning approach to science teacher preparation in D.R. Lavoie and W. - M. Roth (eds.) Models of Science Teacher Preparation, 49-66. Kluwer Academic Publishers. Netherlands.

Rickinson, M., (2003). Reviewing research evidence in environmental education: some methodological reflections and challenges. Environmental Education Research, 9(2), 257-271.

Rickinson, M., (2001). Learners and learning in environmental education: a critical review of evidence. Environmental Education Research, 7(3), 209320.

Savin-Baden, M. (2000). Problem-based Learning in Higher Education: Untold Stories. Buckingham: SRHE and Open University.

Savin-Baden., M. (2001). The problem-based learning landscape. PlanetSpecial Edition Two, November 2001, 4-6. http://www.gees.ac.uk/planet/p4/msb.pdf

Senocak, E., Taskesenligil, Y. and Sozbilir, M. (2007). A study on teaching gases through problem-based learning. Research in Science Education, 37, 279-290.

Shulman, L. S. (1986). Those who understand: Knowledge growth in teaching. Educational Researcher, 15(2), 4-14.

So, H., and Kim, B. (2009). Learning about problem based learning: Student teachers integrating technology, pedagogy and content knowledge. Australasian Journal of Educational Technology, 25(1), 101-116.

Tan, O.S. (2003). Problem-based learning innovation: Using problems to power learning in the twenty-first century. Singapore: Thomson Learning. 
Taplin, M. and Chan, C. (2001). Developing problem solving practitioners. Journal of Mathematics Teacher Education, 4, 285-304.Van de Bossche, P., Gijbels, D. and Dochy, F. (2000). Does problem-based learning educate problem solvers? A meta-analysis of the effects of problem based learning. Paper presented at the Seventh Annual EDINEB International Conference, Newport Beach, CA. van den Bossche, P., Gijbels, D. and Dochy, F. (2000). Does problem-based learning educate problem solvers? A meta analysis of the effects of problem-based learning. Paper presented at the Seventh Annual EDINEB International Conference, Newport Beach, CA.

Vernon, D.T., and Blake, R. L., (1993). Does problem-based learning work? A meta-analysis of evaluative research. Academic Medicine, 68(7), 550-563.

Watters, J. J. (2007). Problem-based learning in pre-service elementary science teacher education: Hostile territory. In proceedings $P B L$ conference in Problem-Based Learning in Undergraduate and Professional Education, Birmingham, Alabama, USA. 